\title{
DETERMINATION OF THE RATIONAL LEVEL OF MECHANIZATION OF ROAD PRODUCTION
}

\section{ВИЗНАЧЕННЯ РАЦІОНАЛЬНОГО РІВНЯ МЕХАНІЗАЦЇ̈ ДОРОЖНЬОГО ВИРОБНИЦТВА}

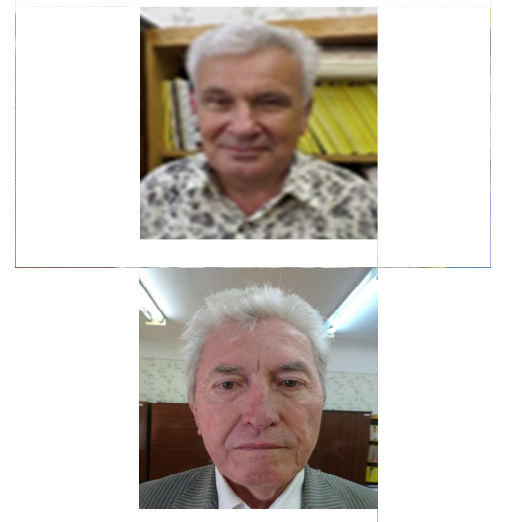

Lykhostup M., PhD, Candidate of Technical Sciences, Associate Professor, Associate Professor, Department of Transportation Construction and Property Management, National Transport University https://orcid.org/0000-0001-8139-1768

Varfolomeev J.U., Associate Professor, Associate Professor, Department of Transport Construction Machines, National Transport University

https://orcid.org/0000-0001-5388-6624

\begin{abstract}
The constant aspiration of a person to replace manual labor with the work of machines and mechanisms is reproduced in such concepts as "mechanization", "automation", "machine-tool" and others. In the construction industry, the most common and most favorable for the disclosure of this desire is an indicator of the level of mechanization. But in the techniques and recommendations that provide advice on the definition of this indicator, its calculation is carried out using generalizations of mechanization of labor without giving any clear representations as to the determination of production volumes in a purely mechanized way.

The article reveals the essence of the indicator of the level of mechanization of road production, which determines the expediency of improving the structure of the main production assets of the enterprise for the implementation of such a program of work, which would contribute to maximizing profits. In general, the definition of the rational level of mechanization is based on the implementation of an iterative algorithm, which includes a number of stages.
\end{abstract}

Thus, at the first stage, the initial (basic) program of a road organization is determined using data on the quantity and quality of the main production assets and the usual program of work for this enterprise. Determining the structure of this program, consisting of a number of road works and labor processes, in turn, is carried out using the developed algorithm, which involves the maximum technological use of all types of resources, including technical, which contribute to the mechanized mode of work. Next, using the data on the structure of the works, it is possible to obtain the estimated value of profit that can be obtained as a result of the implementation of the initial program of work.

On the basis of the information about the estimated value of profit formed part of it in the form of a production development fund. The size of the fund for the development of production is the basis for reforming the machine park of the road organization. Options for changing the quantitative and qualitative composition of the machine park include the steps to assess their residual value, the purchase of new machines, major repairs or replacement of existing units of equipment.

Using the data of various variants of the modernization of the park of machines and mechanisms, the corresponding changes for working hours for them are determined for the year, that is, the initial annual of 
working time is recalculated. The updated information on annual working time funds is used to determine the appropriate modifications to the park of machines of the work program of the road organization. For each option of updated programs of work determined by the calculated profit, and its maximum value is approved rational program of work.

At the last stage, using data on total costs of manual and mechanized labor, as well as data on the total number of performers, indicators are calculated that characterize the level of mechanization of a road enterprise. The obtained indicators, as characteristics of the level of mechanization, can be used to solve various tasks in the field of road production management.

Key words: level of mechanization, program of work, estimated profit, indicators of mechanization.

\section{Presenting main material}

As you know, the level of mechanization of production is used in the processes of enterprise management in order to determine or confirm the sustainability and success of its activities. The indicator of the level of mechanization is used in the process of forming an offer for participation in competitive bidding, as an indicator of the formation of the wage level of the program executors, as a mandatory indicator of enterprise activity reporting, as well as a criterion for evaluating the results of the production and economic activity of the enterprise. In general, the definition and prediction of the indicator of mechanization of production is determined by its relevance and comprehensive necessity.

Determination of the level of mechanization takes place at different levels of production management, that is, it can be determined at the level of individual works, at the level of execution of individual programs of works or contracts or at the level of the entire enterprise. In all these cases, the calculation of the level (indicator) of mechanization of production is quite simple, that is, it is determined by the ratio of volumes of work that were performed mechanized way to the total output $[1,2]$. But the problem of implementing such a method of calculating the level of mechanization lies in the fact that the determination of the fate of "mechanized" share of work in the total volume of production is extremely complex and virtually unresolved problem, because this part of the work can be imagined as the cost of energy workers, whether it is the number of executed products, is it a lot of labor. Therefore, the use to determine the level of mechanization of information on the cost of manual and machine labor or the number of performers (workers and machine operators) will only lead to the calculation of indicators characterizing the level of mechanization.

On the basis of the system-technical analysis of the suburbs of the indicator of the level of production mechanization, it is possible to conclude that it has a relative nature, and therefore its significance does not directly affect the achievement of the best results of production, but, on the other hand, is an inherent characteristic of the organization of production. In general, the level of mechanization should be understood as the tendency to reduce manual labor in the production process, provided that the cost of its production is reduced and that a positive socioeconomic effect is achieved. In road production, as a criterion for achieving a favorable result, the profit that can be obtained as a result of the implementation of the program of work can be best taken.

On the basis of the analysis of the trends in determining the profit in transport construction, one can conclude that in practice only the concept and meaning of estimated profit are actually used. Since the definition of estimated profits is carried out at the design stage as part of a consolidated estimated calculation [2], then in the further material it is a question of a predominant definition of the planned level of both company profits and the possible level of mechanization that contributes to achieving this profit.

Determination of the rational relation between the enterprise activity program with the defined structure of work necessary for its successful implementation by the level of mechanization and planned profit is carried out using the method of iterative modeling of the processes of solving such problem in the following stages:

Науково-технічний збірник «АВТОМОБІльні дОРОГИ І ДОРОЖнє БУдІВнИЦтВО» http://addb.ntu.edu.ua

ISSN 0365-8171 (Print), ISSN 2707-4080 (Online), ISSN 2707-4099 (CD).

AUTOMOBILE ROADS AND ROAD CONSTRUCTION, 2021. Issue 109 


$$
\Pi P 1 \text {-> КП1 -> ПМ -> ПР2 -> КП2; } E=K \Pi 2-K \Pi 1,
$$

where $\Pi$ Р1 - procedures for modeling the processes of implementation of the initial program of works of the enterprise;

KII - calculation of the estimated profit that can be obtained as a result of the implementation of the $\Pi P 1$ program;

$\Pi \mathbf{M}$ - procedures for simulation of processes for improving the condition of main industrial assets;

IP2 - procedures for modeling the implementation of the program of work after the renewal of the main production assets of the enterprise;

KП2 - calculation of estimated profit, which can be received as a result of program $\Pi Р 2$;

$\boldsymbol{E}$ - is the economic effect that can be obtained as a result of the renewal of the structure of the main productive assets.

To solve the stages of the problem (1) a system of initial data that characterizes the activity of a road enterprise is formed and includes:

- list and amount of labor and technical resources available to the road enterprise $-r=1,2, \ldots, R$, where $r$ is the type of resource (or group of resources of one class);

- estimated annual working time fund of each group of resources, which is measured in hum. $x h$ for labor. and for technical resources - in the mash.x $h$ - Fr; which forms the so-called "cash desk" of resources;

- a list of characteristic works and groups of labor processes, which constitute the latest program of work of the road enterprise $-i=1,2, \ldots, n$, where $i$ is the kind of characteristic work (or group of labor processes). The list of characteristic work and labor processes is established on the basis of the analysis of acts on executed work in the form number КБ- $2 \mathrm{~B}$;

- the cost of performing a unit of measurement of a characteristic work or a group of labor processes $\mathrm{Ci}$, which can be determined from acts № КБ-2B, UAH;

- calculation of the technologically possible duration of a typical work or a dedicated group of labor processes - Ti, h.

The source data system also includes a normative base on the cost of resources per unit of measurement of a characteristic work or group of labor processes, which uses state Resource Element Estimates (RECNs - PEKH) [4,5]

Procedures for simulating the processes of implementing the enterprise program's initial program of work - ПP1 begin with the determination of the feasibility of each $i$ - th work characteristic of this program throughout the year, during the period Ti. For this purpose, for each work, the level of its provision with resources is set, which can be demonstrated by such an example.

The characteristic work corresponds to REKN - DSTU B D.2.2 - 2013, Sb. 27, tab. 27 - 14 [4]. Unit of measurement of this work $-100 \mathrm{~m}^{3}$, the estimated time of its execution is 600 hours. A fragment of the calculation of the level of resource provision is presented in the table 1. 
Table 1 - A fragment of the results of calculating the level of provision of resources

Таблиця 1 - Фрагмент результатів розрахунку рівня забезпечення ресурсами

\begin{tabular}{|c|c|c|c|c|c|c|c|}
\hline \multirow{2}{*}{$\begin{array}{l}\text { Name } \\
\text { resources }\end{array}$} & \multirow{2}{*}{$\begin{array}{l}\text { Number of } \\
\text { enterprise } \\
\text { resources }\end{array}$} & \multicolumn{2}{|c|}{$\begin{array}{l}\text { Resource expenditures } \\
\text { per } 100 \mathrm{~m}^{3}(\mathrm{PEKH})\end{array}$} & \multirow{2}{*}{$\begin{array}{l}\text { Maximum } \\
\text { volume of } \\
\text { work, } \mathrm{m}^{3} \\
\quad V \max \end{array}$} & \multirow{2}{*}{$\begin{array}{l}\text { Costs } \\
\text { resource } \\
\text { resource } \\
\text { on } \\
\text { Vmax } \\
\end{array}$} & \multirow{2}{*}{$\begin{array}{l}\text { Take } \\
\text { into } \\
\text { conside } \\
\text { ration }\end{array}$} & \multirow{2}{*}{$\begin{array}{l}\text { The coeffi } \\
\text { cient is se- } \\
\text { cured by } \\
\text { resources } \\
\text { Kзp., ir }\end{array}$} \\
\hline & & $\begin{array}{c}\text { unit } \\
\text { measuring }\end{array}$ & $\begin{array}{c}\text { cost } \\
\text { resources }\end{array}$ & & & & \\
\hline 1 & 2 & 3 & 4 & 5 & 6 & 7 & 8 \\
\hline $\begin{array}{l}\text { 1. Cost of labor } \\
\text { (workers) }\end{array}$ & 68 & hum. $x \mathrm{~h}$ & 17,9 & 33835 & 6056 & 10,1 & 6,73 \\
\hline $\begin{array}{l}\text { 2.Motor } \\
\text { gradars, } \\
99 \mathrm{KW}\end{array}$ & 3 & mash. $\times \mathrm{h}$ & 5,32 & 33835 & 1800 & 3 & 1 \\
\hline $\begin{array}{c}\text { 3. Road roller, } \\
13 \mathrm{t} \\
\end{array}$ & 2 & mash. $\mathrm{x} \mathrm{h}$ & 22,92 & 33835 & 7755 & 12,93 & 0,15 \\
\hline$\ldots$ & . . & $\cdots$ & & & & 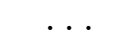 & \\
\hline
\end{tabular}

The maximum amount of work - Vmax is determined by the performance of the lead resource, which in this case adopted an motor grader. Then:

$V \max =(600 / 5,32) \times 100) \times 3=33835 \mathrm{~m}^{3}$

Resource Coefficient - Kзp., $i \mathrm{r}$ (column 8, table 1) is determined by dividing column data 2 into column data 7 . The estimated factor providing the resources of the above work is the minimum value of all the supply factors for each type of resource, that is, 0.15 , that is $K з$.,, $\mathrm{i}=0.15$.

Then, depending on the value of the coefficients of providing resources, all the characteristic work and labor processes are divided into 2 groups. The first group includes such works and labor processes in which Кзр., $i>1$, that is, the enterprise has enough resources to perform this work (or labor process) throughout the technological period. The second group includes such works and labor processes in which Kзр., $i<1$.

From these two groups there is a general ordered "queue" of work and labor processes, which begins with their ordering in the first group. In this case, the work (or labor process) which has a higher specific value - PSi, which is calculated as: $P S i=(\operatorname{Vmax} x \mathrm{Ci}) / \mathrm{Ti}$, occupies a higher place. The characteristic work (labor processes) is arranged in order of decreasing their coefficient of providing resources - Кз $p ., i$.

Formation of the initial (basic) program of work - $\Pi P 1$ is carried out by allocating according to certain rules and in a certain sequence from the "cash desk" resources of their required volumes for each work (labor process). Allocation of resources from their "cash desk" represents a system of simulation procedures that are implemented in the following sequence:

- to the first in a ranged sequence of work and labor processes is provided "cash" resources, from which "selected" part of the resources necessary for this work - Fir, $z$, where $z=1,2, \ldots, Z$ is the number of the iterative step of allocating resources for work and labor processes. Necessary part of resources is determined by the multiplication of the time available for the time allocation of the resource, which is in the current "cash desk", by the ratio of demand - Knomp., ir, $z$ [6]. This coefficient is determined on the basis of the information on the maximum and the limited (allowable by the coefficients of provision) the volume of production of all works and work processes, the timing of their execution and the performance of the leading resources. Thus, after the "provision" of the first work or labor resource process in the amount of Fir, 1 , in the "cash register" a balance is formed that is used to meet the needs of the subsequent work (labor process);

- the resources remaining after the previous distribution in the "cash register", are transferred to the subsequent work (labor process) in accordance with the specified order. Next, for this subsequent work (process), the necessary amount of resources is calculated $-F(i+1) r, 1$ in accordance with the demand-calculated by current information - Knomp., $(i+1) r, 1$;

- then the residual after the previous use of the "cash register" of resources is "passed" to the queue of work (labor process) until such time as all work and processes of the program of work are secured in accordance with a definite part. This completes the first iteration of resource allocation, $z=1$; 
- then the distribution of resources is carried out for the following iterations, when $z=2,3, \ldots, Z$. The expansion of resources ends on that iteration, that is $Z$, when the residual "box office" will not find the necessary resource for the next labor process. This iteration is canceled and the resource allocation is stopped. In principle, the number of iterations can be calculated (the formula in the article is not given), but, as the practice of the calculations performed shows, their number is from 7 to 12 .

In parallel with the allocation of resources for work and labor processes, at each iteration, the volume of work that can be performed by the given part of resources - Vi, $z$, and their sum over all iterations gives the opportunity to determine the total amount of each work (or labor process) - $\underline{V}$, and in the general form of their list and the physical expression forms the initial program of works - IP1. In addition, the calculation of the spent working time of each resource is made - Fr, вump. and the remainder after the time allocation is $F r$, залиш. The information makes it possible to take further decisions that the resource base of the company and streamlining the work program. So, for example, with data value fund of working time each resource - Fr, витp. expended in carrying out the program of work and remaining after the distribution of stock of time - - Fr, залиш. may calculate the amount of each $r$ - th resource used respectively during execution program of work and remains unused after its execution. Such information is the basis for drawing up the so - called balance of resources.

First of all, for the determined initial program of work - $\Pi P 1$ calculated estimated arrived - KПI in accordance with the provisions of the existing sectoral documents [4]. According to the method of determining profit, its value mainly depends on the value of the work performed (in other words, on the volumes of production) and the structure of labor, that is, the relation between manual and mechanization labor. But in any case, profits are a generator of the formation of late economic foundations, among which there is a fund for the development of production and serves as a source of improvement of the quantitative and qualitative state of the main productive assets, and first of all - working machines and mechanisms.

Procedures for modeling the processes of improving the state of the main production assets represent a definition of possible options for changing the quantity and quality of machines and mechanisms. In general, the designation of the options for the modernization of the machine park $-v$ (where $-v=1,2, \ldots V$ ) appears as a sequence of expert procedures, each of which has its purpose. So, with the formation of options for the modernization of the machine park, opportunities can be considered:

estimates of the state of machines and mechanisms at residual value [7] and their replacement for new ones in order to obtain negative results;

the purchase of new machines and mechanisms that are inadequate in the road organization, which caused the suspension of the development of the program of work at the stage of distributing the "cash" of resources for work and ore processes;

major repairs of machines that are close or perish the terms of their lifetime.

Formation of each variant of the change in the quantitative and qualitative composition of the machine park is carried out within the framework of a definite development fund for testing. For any variant of the change in the machine park, the annual funds of working time for those resources that are subject to change in the appropriate version are $F r, v$ (where $-r=1,2, \ldots R ; v=1,2, \ldots V$ ).

Thus, new values of annual working time resources of all resources are formed, which serve as the initial data for modeling the processes of implementation of the program of work after the renewal of the main production assets of the enterprise - ПP2. For each of the $v$ - their variants of the modernization of the machine park, and accordingly to the change in the annual resources of working time resources, formed options for annual work programs $-\Pi P 2$, $v$. For each option of the updated program of work the profit is calculated $-K \Pi 2$, $v$, but as the final version of the perspective program of work, the one that corresponds to the maximum profit value $-K \Pi 2, v \rightarrow \max$ is taken.

Using the information on the structure of the program of work, both $\Pi P 1$ and $\Pi P 2$, indicators that characterize the level of mechanization - $\Pi M$ according to the formulas can be calculated:

$$
P M=\frac{T P_{\mathcal{M}}}{T P_{P}+T P_{\mathcal{M}}} \quad \text { or } \quad P M=\frac{M}{(M+P)},
$$

where $T P_{\mathcal{M}}$ - the complexity of work performed mechanized way, that is, mechanized, mash.x $h$;; $T P p$ - total labor complexity of manual labor, hum. $x h$; 
$M$ - number of machines in the production unit, person;

$P$ - number of workers in the production unit, people.

Obtained by the formulas of indicators of the $\Pi M$, characterizing the level of mechanization, can be taken to improve the practical activities of the enterprise. But even in this case, a comparative analysis of the comparison of values of indicators of the level of mechanization of $\Pi M$, that can be obtained as a result of programs $\Pi P 1$ and $\Pi P 2$ is useful.

\section{Conclusions}

The article presents one of the approaches to the assessment of the nature of the level of mechanization of production, based on the idea of its development in order to implement a more perfect program of work of the enterprise and achieve more profits. The definition of rational relations between the structure of the production program of the enterprise, the quantitative and qualitative composition of the main productive assets and the profit is realized on the basis of an iterative expert - analytical model. The obtained indicators of estimation of the level of mechanization of road production can be used to evaluate the activity of road economy units at different levels of management.

\section{References}

1. Kudrjavzev E. M. Kompleksnaja mechanizazija, avtomatizazija i mechanovooruschennost stroitelstva. /E. M. Kudrjavzev - M.: Stroyizdat, 1989. - 246 s.

2. Belezkiy B. F. Technologija i mechanizazija stroitelnogo proizvodstva. Izd. 3 - th. /B. F. Belezkiy - Rostov n/D: Rostov, 2004. - $752 \mathrm{~s}$.

3. DSTU - N B D.1.1-3:2013. Nastanova schto do vyznachennja zagalnovyrobnychyx i administratyvnyx vytrat ta prybutky u vartocti budivnyztva // Minregion Ukrainy. - K:, 2013. - $36 \mathrm{c}$.

4. DSTU B D.2.2. Resursni elementni koshtorysni normy na budivelni roboty. Zb. 1 - 30, (REKN) // Minregion Ukrainy. - K:, 2013.

5. SOU 45.2-00018112-035:2010. Resursni elementni koshtorysni normy na remontno-,udivelni roboty. Avtomobilni dorogy i mosty. // Derschavna sluschba avtomobilnyx dorig Ukrainy (Ukravtodor). - K:, $2010-216$ s.

6. Likhostup M.M., Leont'ev JU.M. Vplyv faktora vyznatschennja vyrobnytyschoi potuschnosti na riven vykorystannja resursav d doroschniy galyzi. /Avtomobilni dorogy i doroschne budivnyztvo. - Vyp. 63. - K: Vyd-vo NTU, 2001. - S.148 - 151.

7. Kovalev A. P. Ozenka stoimosri aktivnoy tschasti osnovnych fondov / A. P. Kovalev - M.: Finstatinform, 1997. - $175 \mathrm{~s}$.

8. Garmanov E. N. Ekonomitcheskaja effektivnost doroschnogo xozjaystva. /E. N. Garmanov - M.: Transport, 1984. $-173 \mathrm{~s}$.

\section{ВИЗНАЧЕННЯ РАЦІОНАЛЬНОГО РІВНЯ МЕХАНІЗАЦЇ̈ ДОРОЖНЬОГО ВИРОБНИЦТВА}

Лихоступ Микола Миколайович, кандидат технічних наук, доцент, доцент кафедри транспортного будівництва та управління майном Національного транспортного університету, https://orcid.org/0000-0001-8139-1768

Варфоломсєв Юрій Миколайович, кандидат технічних наук, доцент кафедри дорожніх машин Національного транспортного університету, https://orcid.org/0000-0001-5388-6624

Анотація. Постійне прагнення людини до заміни ручної праці на роботу машин і механізмів відтворюється в таких поняттях як “механізація", “автоматизація”, “механоозброєність” та інших. В будівельному виробництві найбільш розповсюдженим та найбільш сприятливим для розкриття цього прагнення $\epsilon$ показник рівня механізації. Але в методиках та рекомендаціях, в яких надані поради визначення цього показника, його розрахунок здійснюється із використанням узагальнюючих уявлень про механізацію праці без надання будь - яких чітких уявлень що до визначення обсягів виробництва насправді чисто механізованим способом.

В статті розкривається суть показника рівня механізації дорожнього виробництва, який визначає доцільність удосконалення структури основних виробничих фондів підприємства для виконання такої

Науково-технічний збірник «АвтомОБІльні доРОГи г доРОжнє БУдІвництво» http://addb.ntu.edu.ua

ISSN 0365-8171 (Print), ISSN 2707-4080 (Online), ISSN 2707-4099 (CD).

AUTOMOBILE ROADS AND ROAD CONSTRUCTION, 2021. Issue 109 
програми робіт, яка сприяла б досягнення максимального прибутку. В цілому визначення раціонального рівня механізації базується на реалізації ітеративного алгоритму, який включає в себе ряд етапів. Так на першому етапі визначається початкова (базова) програма дорожньої організації із використанням даних про кількість та якісний стан основних виробничих фондів та звичну для цього підприємства програму робіт. Визначення структури цієї програми, що складається із ряду дорожніх робіт та трудових процесів, в свою чергу здійснюється із використанням розробленого алгоритму, який передбачає максимальне технологічне використання всіх видів ресурсів, в тому числі і технічних, які сприяють механізованому способу виконання робіт. Далі із використанням даних про структуру робіт можливо отримати розрахункове значення прибутку, який може бути отриманий в результаті виконання початкової програми робіт.

На основі інформації про розрахункове значення прибутку формується його частина у вигляді фонду розвитку виробництва. Величина фонду розвитку виробництва $є$ основою для реформування машинного парку дорожньої організації. Варіанти зміни кількісного та якісного складу машинного парку передбачають етапи оцінки їх залишкової вартості, придбання нових машин, капітального ремонту або заміни існуючих одиниць техніки.

Із використанням даних різних варіантів модернізації парку машин та механізмів визначаються і відповідні для них зміни робочого часу роботи на протязі року, тобто перераховуються початкові річні фонди робочого часу. Змінена інформація про річні фонди робочого часу використовується для визначення відповідних до варіантів змін парку машин програм робіт дорожньої організації. Для кожного варіанту оновлених програм робіт визначається розрахунковий прибуток, а за його максимальним значенням затверджується раціональна програма робіт.

На останньому етапі із використанням даних про сумарні витрати ручної та механізованої праці, а також даних про кількість виконавців, розраховуються показники, які характеризують рівень механізації дорожнього підприємства. Отримані показники, як характеристики рівня механізації, можуть бути використані для вирішення різноманітних задач в сфері управління дорожнім виробництвом. нізації.

Ключові слова: рівень механізації, програма робіт, розрахунковий прибуток, показники меха-

\section{Перелік посилань}

1.Кудрявцев Е. М. Комплексная механизация, автоматизация и механовооруженность строительства. /Е. М. Кудрявцев - М.: Стройиздат, 1989. - 246 с.

2. Белецкий Б. Ф. Технология и механизация строительного производства. Изд. 3 - е. /Б. Ф. Белецкий - Ростов н/Д: Ростов, 2004. - 752 с.

3. ДСТУ-Н Б Д.1.1-3:2013. Настанова щодо визначення загальновиробничих і адміністративних витрат та прибутку у вартості будівництва // Мінрегіон України. - К:, 2013. - 36 с.

4. ДСТУ Б Д.2.2. Ресурсні елементні кошторисні норми на будівельні роботи. 3б. 1 - 30, (РЕКН) // Мінрегіон України. - К:, 2013.

5. СОУ 45.2-00018112-035:2010. Ресурсні елементні кошторисні норми на ремонтно-будівельні роботи. Автомобільні дороги і мости // Державна служба автомобільних доріг України (Укравтодор). $-\mathrm{K}:, 2010-216 \mathrm{c}$.

6. Лихоступ М.М., Леонтьєв Ю.М. Вплив фактора визначення виробничої потужності на рівень використання ресурсів в дорожній галузі / Автомобільні дороги і дорожнє будівництво. - Вип. 63. - К: Вид-во НТУ, 2001. - С.148 - 151.

7. Ковалев А. П. Оценка стоимости активной части основных фондов / А. П. Ковалев - М.: Финстатинформ, 1997. - 175 с.

8. Гарманов Е. Н. Экономическая эффетивность дорожного хозяйства. /Е. Н. Гарманов - М.: Транспорт, 1984. - $173 \mathrm{c}$. 